\title{
Effect of supplementary pollination by different pollinizers on fruit set and nut physicochemical traits of 'Supernova', a self-compatible almond
}

\author{
Mousa Rasouli ${ }^{1, \star}$ and Ali Imani ${ }^{2}$ \\ 1 Horticulture and Landscape Department, Faculty of Agriculture, Malayer University, P.O. Box 65719-95863 Malayer, Iran \\ 2 Horticultural Departments of Seed and Plant Improvement Institute (SPII), P.O. Box 31585-4119 Karaj, Iran
}

Received 7 July 2015 - Accepted 18 May 2016

\begin{abstract}
Introduction. Most commercial almonds are self-incompatible and growing these cultivars would increase orchard management costs. Self-compatible almond cultivar cultivation seems to be the solution to increase the yield and reduce the production costs. Materials and methods. In this study, the self-compatible almond cultivar Supernova was used as a seed parent and hand pollinated by the pollen of 'Shahrood 21', 'Shahrood 12', 'Fra Giulio Grande', '410 ', '11-5', and 'Supernova' itself. Also, two pollination methods were used, using 'Supernova' non-emasculated vs. emasculated flowers. Pollen tube growth of these pollinizers was studied by fluorescent microscopy at different times from flower samples harvested at 24, 48, 72, 96 and $120 \mathrm{~h}$ after hand pollination. The composition of fatty acids and the main characteristics of the fruit in the seed parent 'Supernova' were recorded after fruit harvest. Results and discussion. Although all pollens of the used pollinizers were compatible on 'Supernova' and had satisfied fruit set, significant differences were observed among pollinizers in stages 2 and 3. The highest fruit set was achieved when 'Shahrood 21' pollen was used, while the lowest fruit setting was recorded in 'Supernova' by self-pollination. Microscopic observation at $120 \mathrm{~h}$ after pollination revealed that pollen tubes of all pollinizers reached the ovary of 'Supernova'. In this study, fatty acid content was varied with oleic acid between 70.11 to $77.76 \%$, linoleic acid from $4.0 \%$ to $5.5 \%$, palmitic acid from 6.17 to $6.73 \%$, stearic acid from 1.50 to $1.91 \%$, palmitoleic acid from $0.40 \%$ to $0.47 \%$, arachidic acid from 0.1 to $0.4 \%$, gadoleic acid from $0.05 \%$ to $0.06 \%$ and total oil content was between 50.25 to $51.59 \%$. Conclusion. This experiment revealed that different pollen sources had a significant effect on fruit setting, but not in the oil content and fatty acid composition of the seed parent kernels.
\end{abstract}

Keywords: Iran / almond / Prunus dulcis / pollen germination / sexual compatibility / $S_{f}$ allele / fruit quality / nutritional value

Résumé - Effet d'une pollinisation complémentaire par différents pollinisateurs sur la mise à fruit et les caractéristiques physico-chimiques des amandes de l'amandier auto-compatible 'Supernova'. Introduction. La plupart des amandes commerciales sont auto-incompatibles et la culture de ces cultivars augmenterait les coûts de gestion des vergers. La culture de cultivars d'amandier auto-compatibles semble être la solution pour augmenter le rendement et réduire les coûts de production. Matériel et méthodes. Dans cette étude, le cultivar d'amandier autocompatible 'Supernova' a été utilisé en tant que parent semencier pollinisé à la main par le pollen de «Shahrood 21 », «Shahrood $12 »$, «ra Giulio Grande », «4-10», «11-5» et « Supernova » lui-même. En outre, deux méthodes de pollinisation ont été utilisées selon que les fleurs de «Supernova » étaient émasculées ou non. La croissance du tube pollinique de ces pollinisateurs a été étudiée par microscopie à fluorescence à différents stades à partir d'échantillons de fleurs récoltées $24,48,72,96$ et 120 h après pollinisation. La composition en acides gras et les principales caractéristiques du fruit généré sur le pied-mère "Supernova » ont été enregistrées après récolte. Résultats et discussion. Si tous les pollens des pollinisateurs utilisés se sont montrés compatibles avec « Supernova» et ont conduit au stade nouaison de façon satisfaisante, des différences significatives ont toutefois été observées entre pollinisateurs aux stades 2 et 3 . Le taux de mise à fruit le plus élevé a été atteint avec le pollen de «Shahrood 21 », tandis que le plus bas a été enregistré avec «Supernova» en auto-pollinisation. L'observation au microscope $120 \mathrm{~h}$ après pollinisation a révélé que les tubes polliniques de tous les pollinisateurs ont atteint l'ovaire de «Supernova ».

\footnotetext{
^ Corresponding author: m.rasouli@malayeru.ac.ir
} 
L'étude de la teneur en acides gras a montré des variations de l'acide oléique entre 70,11 à 77,76\%, l'acide linoléique de $4,0 \%$ à $5,5 \%$, l'acide palmitique de 6,17 à $6,73 \%$, l'acide stéarique de 1,50 à $1,91 \%$, l'acide palmitoléique de $0,40 \%$ à $0,47 \%$, l'acide arachidique de 0,1 à $0,4 \%$, l'acide gadoléique de $0,05 \%$ à $0,06 \%$, pour une teneur totale en huile comprise entre 50,25 à 51,59\%. Conclusion. Cette expérience a révélé que les différentes sources de pollen ont un effet significatif sur la nouaison, et pas sur la composition en acide gras ni sur la teneur en huile des amandes parentales.

Mots clés : Iran / amandier / Prunus dulcis / germination pollinique / compatibilité sexuelle / allèle $S_{f} /$ qualité du fruit / valeur nutritionelle

\section{Introduction}

Almond (Prunus dulcis Miller D.A. Webb) is among the most important temperate nut crops with high economical value for easy harvesting, simple preservation and the transportation, good adaptation to calcareous soils and semi arid regions, high nutrient value and enough diversity for selection [1]. Unfortunately, most commercial almonds are selfincompatible that necessitates cross-pollination with compatible and overlapped blooming time types [2]. Self- and cross-incompatibility in almond is controlled gametophytically where cytotoxic proteins are produced in the stigmatic and transmitting tissue $[1,3]$. In practice, recognition compatible and incompatible groups of almond cultivars are economically important. Also management costs for growing selfincompatible almond cultivars in multi-cultivar orchards with ecological dependent fertilization especially in the unsuitable conditions for insect pollinators are the main concerns for growers. For these reasons, self-compatible almond is a choice of interest in many breeding programs [4-11].

All of the known cultivars of the self-compatible almond are heterozygous in locus $S\left(S_{x} S_{f}\right)$, and also homozygous selfadaptable cultivars of almond have been obtained by the programs of breeding [12-14]. Among the heterozygous selfcompatible cultivars, $50 \%$ of the pollens are $S_{f}$ and compatible to reach ovary, but in completely compatible cross pollination it would be $100 \%$. The percentage of fruit set in case of selfor cross-pollination in self-compatible genotypes of almond has commonly showed different results $[2,12,15-18]$. Some studies have focused on using different pollination treatment effects on different aspects of fruit particularly fruit physical traits including kernel weight, percentage of double kernels, weight in-shell, kernel weight, nut volume and kernel volume of the new self-compatible cultivars $[2,15,18]$. This attention has always been paid to the almond due to it having effective materials such as fiber, vitamin, mineral elements, as well as antioxidant properties. Not only oil of almond seeds is used as a food in the diet but also used in making cosmetic detergent creams, soap and perfumery industries for preventing the itching of the skin and the acnes [19]. Pharmaceutically, almond oil plays a role in reducing heart disease by conserving the useful cholesterols (HDL) and by reducing the total harmful cholesterol content (triglyceride and LDL). More recently some research has been looking to identify and access almond cultivars with high oil in seeds [14].

Due to the importance of evaluating the commercial behavior of self-compatible almond cultivars and inconsistencies between several recent studies, the aim of this work was to study the possible influence of pollen source on fruit set and fruit chemical and physical traits of self-compatible almond 'Supernova'.

\section{Materials and methods}

\subsection{Seed parent and pollen sources}

In this experiment, a self-compatible almond Prunus dulcis cv. Supernova was considered as the seed parent and hand pollinated with six pollen source including 'Shahrood 21', 'Shahrood 12', 'Fra Giulio Grande', '4-10', '11-5', and 'Supernova' itself using two pollination methods (unemasculated $v s$. emasculated of 'Supernova' flowers as seed parent).

This experiment was performed for three years (20082010) in the Seed and Plant Improvement Institute (SPII) orchards at Kamal Abad area, located $15 \mathrm{~km}$ west of Alborz province. This area is located in Alborz province, at $36^{\circ} 08^{\prime} 27^{\prime \prime} \mathrm{N}$ latitude, $50^{\circ} 03^{\prime} 26^{\prime \prime} \mathrm{E}$ longitude and $1,270 \mathrm{~m}$ above the sea level, with an annual average temperature of $13.8{ }^{\circ} \mathrm{C}$ and an annual average precipitation of $260 \mathrm{~mm}$. During three years, after hand pollination, pistils were collected and placed in small glass vials containing FAA for later microscopic analysis.

For collected pollen branches with $0.5-1.0 \mathrm{~m}$ length and enough flower buds were cut at swelling stage and transferred to the lab. Also, 'Supernova' branches in different parts of the trees were labeled in the swelling phase of the flower buds (Balloon stage), and then flowers were isolated in bags with dimensions of $50 \times 70 \mathrm{~cm}$ carefully and emasculated to prevent self-pollination.

In order to pollinate with the considered pollens, according to the time of flowers opening on each branch, after removing the mull bags, 80-130 flowers were preserved and the other flowers were omitted. The removed flowers included the unopened flowers and the flowers that have been already opened.

To study pollen germination ability in vitro, anthers were sampled from all mentioned cultivars grown at the same orchard at the late balloon stage. Collected anthers were dried in an incubator at $20-22{ }^{\circ} \mathrm{C}$ until dehiscence, which usually took about $24 \mathrm{~h}$ and the germination tests were carried out immediately. Germination medium consisted of $1 \%$ agar and $15 \%$ sucrose, and prepared by dissolving them in boiling water at $\mathrm{pH}$ 5.6. The mixture was divided into $90-\mathrm{mm}$ Petri dishes, and pollen was scattered onto the medium surface after cooling and 
incubated for $6 \mathrm{~h}$ at $25^{\circ} \mathrm{C}$. The percentage of pollen germination was determined under a light transmission microscope. Pollen grains with elongated tubes equal to or longer than the diameter of the pollen grain were recorded as germinated ones.

At 24, 48, 72, 96 and $120 \mathrm{~h}$ after pollination, pistils were collected and placed in small glass vials with $5 \mathrm{~mL}$ of FAA, a fixing solution made up of $40 \%(\mathrm{v} / \mathrm{v})$ formaldehyde, $90 \%(\mathrm{v} / \mathrm{v})$ glacial acetic acid and 70\% (v/v) ethanol in a ratio of 1:1:18. The pistils were washed and autoclaved for $30 \mathrm{~min}$ at a pressure of $1 \mathrm{~kg} \mathrm{~cm}^{-2}$ in a solution of $5 \%$ sodium sulphite to soften the tissue and to enhance the staining with $0.1 \%$ aniline blue in $0.1 \mathrm{~N}$ potassium phosphates. Pistils was stripped of their pubescence carefully and were placed on slides, crushed and examined by fluorescence microscopy 4X (Olympus model: BX51 TRF, Japan) in the nanotechnology lab of the Agriculture Biotechnology Research Institute of Iran (ABRII) [2].

\subsection{Fatty acid composition, oil content and fruit characteristics}

In this experiment, at least 10 almond kernels of each pollination combination with 3 replications were examined. Their oil percentage was determined according to the method of Foma and Abdola [20]. Fatty acid composition also was measured in accordance with the method of Kodad and Socias i Company [14]. To study fruit characteristics, at least 20 mature fruits from each pollination combination were hand-harvested, the hulls removed and nuts dried at room temperature for 4 weeks based on the method described by Dicenta et al. [2]. Some important fruit traits usually evaluated in almond breeding programs [11] were analyzed. The traits of weight in-shell, shell hardness, kernel weight, kernel percentage, double kernel percentage, kernel thickness, and kernel color were evaluated in the horticulture lab of the Seed and Plant Improvement Institute (SPII) in Karaj, Iran, in accordance to the almond descriptor [21] and following the methods described by Ortega et al. [18].

\subsection{Statistical analyses}

The main experiment was performed with 6 treatments and 4 replications in a completely randomized design (CRD). All data were subjected to an analysis of variance (ANOVA) using the SAS software (v. 9.2), and the compression between means was evaluated by the Duncan test at a $P=5 \%$ level.

\section{Results and discussion}

\subsection{Pollen germination}

Collected pollens from pollinizers were cultured at several times in in vitro conditions, in order to ensure their viability. Pollen germination rates of different pollinizers were found between 65 and $78 \%$.

Pollen germination showed some variability (nearly $80 \%$ germination) between cultivars and genotypes. It indicated that pollens used in this study were efficient and suitable for further use in controlled pollination. These values were higher than self-compatible genotypes reported in CEBAS, Spain (3674\%) [2]. Pollen germination results in this research were lower than those reported for self-incompatible local cultivars from Murcia in Spain (68-94\%) [2]. In almond, to have suitable pollination, high fruit set and high quality fruit, a large number of self-compatible cultivars is required. In general, heterozygous self-compatible genotypes behave the same way when self- or cross-pollinated, although half of the pollen tubes are expected to stop along the style after selfing [2].

\subsection{Pollen tube growth through style and ovary}

Analysis of variance showed significant differences among cultivars, the times between pollination to fixation and pollination of emasculated or non-emasculated flowers for the number of pollen tubes in the ovary (tables I-II and figure 1). Also, significant differences were found for cultivar $\times$ time interaction (figure 1). Interactions of cultivar $\times$ pollination, time $\times$ pollination and cultivar $\times$ pollination $\times$ time were not significant $(t a-$ bles I-II). The results of microscopic observations showed that all cultivars and genotypes were compatible to 'Supernova'. In all samples, pollen tubes reached to ovary of 'Supernova' were dependant to pollinizer. The effect of time was significant and there were no differences between self- and cross-pollinated 'Supernova'.

Results indicated that pollen tube growth of 'Supernova' had decreased in one-third of the style. However, pollen tubes of these cultivars were reached to end of the style $120 \mathrm{~h}$ after pollination when fertility occurred (table II and figure 1). These results confirmed 'Supernova' cultivar to be self-compatible (table II and figure 1). Also, time for pollen tube growth of 'Shahrood 21', 'Shahrood 12', '4-10' and '11$5^{\prime}$ ' in style tissue was between $48-120 \mathrm{~h}$ after pollination (table II and figure 1). Other researchers experimented on pollen tube growth all along the style in self-compatible cultivars $[2,4,6,23,27]$. The present research tested the pollen tube growth looking at the total style length and the longest pollen tubes across, and our results are in accordance with these authors.

At $24 \mathrm{~h}$ after pollination of emasculated and nonemasculated flowers, none of the pollinizer pollen tubes reached the ovary of 'Supernova' (table II). Dicenta et al. [2] reported similar result for six self-compatible almond cultivars at 24, 48, 72 and $96 \mathrm{~h}$ after self- and cross-pollination with pollen from 'Ramillete'. Pollen tubes of 'Feragello' did not reach the ovary $48 \mathrm{~h}$ after pollination but for the other pollinizers, pollen tubes reached the ovary after $48 \mathrm{~h}$ (table II). Although, 'Supernova' and 'Fra Giulio Grande' have the same genotype for the $\mathrm{S}$ allele $\left(S_{1} S_{f}\right)$, there could be some physiological incompatibility or inbreeding effects between these two self-compatible cultivars at an early stage of the pollen tube growth. Pollen tubes of the other pollinizers were able to reach the style base in high numbers in most pistils. Thus, the physiological self-incompatibility observed could not be due to a deficiency of the energy storage in the pistil transmitting tissue [28], because pistils were able to release all nutrients for attraction, guidance, and signaling of foreign pollen tubes. 


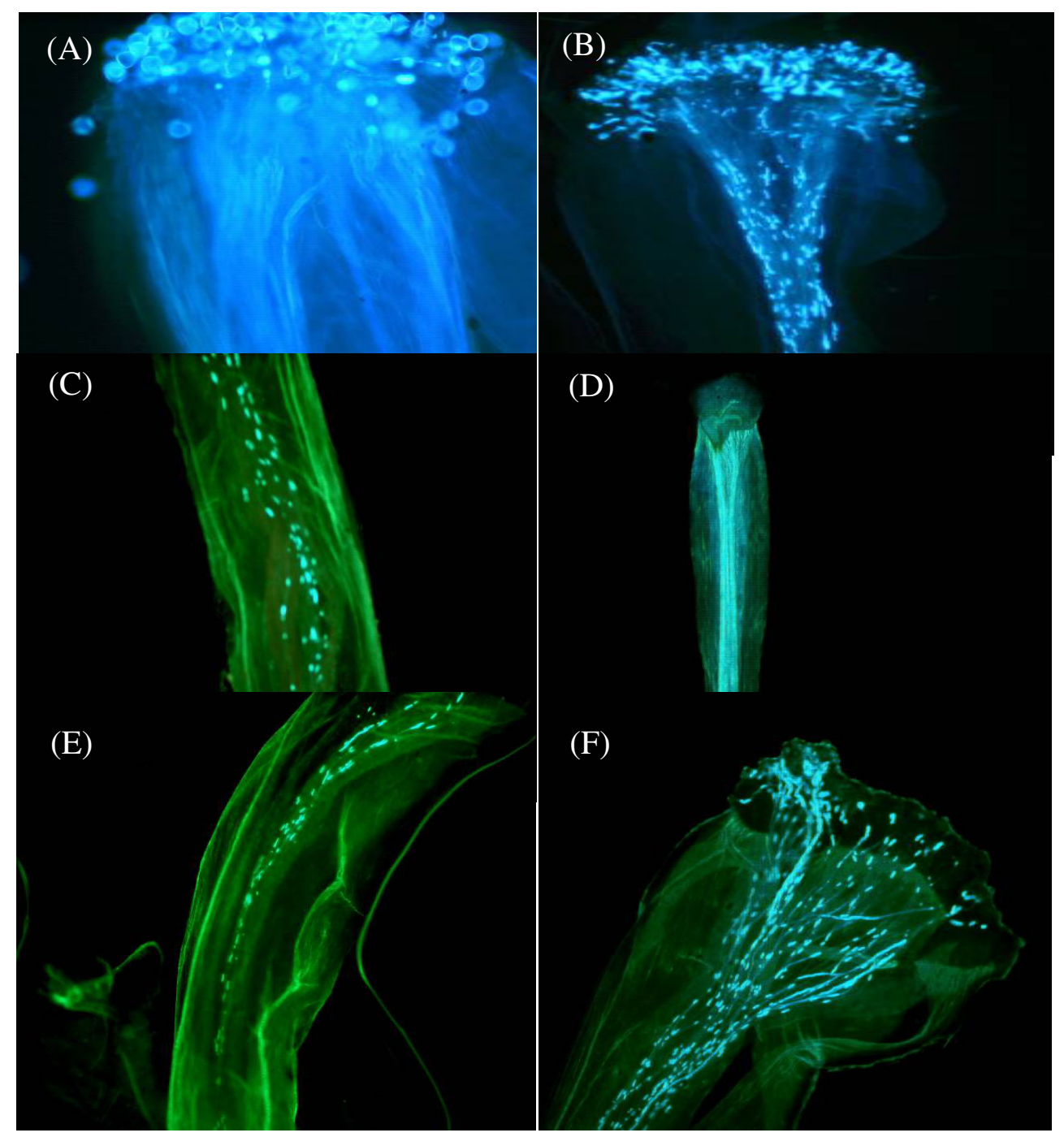

Figure 1. (A): Germination of 'Supernova' pollen $\left(\sigma^{7}\right)$ on the self stigma and pollen tube growth in the first part of style of 'Supernova' ( $(9)$ (96 h after pollination). (B): Pollen tube growth of 'Shahrood 21' from stigma to the end part of style of 'Supernova' ( + ) (96 h after pollination) (A and B in the first year of experiment). (C): Pollen tube growth of 'Supernova' ( $\sigma^{\prime}$ ) in the one third part of the style of 'Supernova' ( + ) (120 $\mathrm{h}$ after pollination). (D): Pollen tube growth of 'Shahrood 21' from stigma to the end part of style of 'Supernova' (Q) (120 h after pollination) (C and D in the second year of experiment). (E): Pollen tube growth of 'Shahrood 12' ( $\left.\sigma^{7}\right)$ in the one third part of the style of 'Supernova' ( + ) (120 h after pollination). (F): Pollen tube growth of '11-5' from stigma to the one third part of style of 'Supernova' (ㅇ) (120 h after pollination) (E and $\mathrm{F}$ in the third year of experiment) (Fluorescence microscopy 4X, $200 \mu \mathrm{m}$ ).

Table I. Analysis of variance for the number of pollen tubes of six almond cultivars reaching the ovary of 'Supernova' at 24, 48, 72, 96 and $120 \mathrm{~h}$ after self-pollination and cross-pollination.

\begin{tabular}{llllll}
\hline Stream of variation & DF & Sum of square & Mean square & F (Value) & Probability \\
\hline Cultivar & 5 & $22,074.499$ & $4,414.90$ & $60.41^{1 * *}$ & 0.0001 \\
Time & 4 & $70,602.30$ & $17,650.57$ & $241.53^{* *}$ & 0.0001 \\
Pollination & 1 & 364.85 & 364.85 & $4.99^{*}$ & 0.0273 \\
Cultivar $\times$ Time & 20 & $12,415.11$ & 620.75 & $8.49^{* *}$ & 0.0001 \\
Cultivar $\times$ Pollination & 5 & $2,565.57$ & 513.11 & $7.02^{\text {ns }}$ & 0.0706 \\
Time $\times$ Pollination & 4 & 214.52 & 53.63 & $0.73^{\text {ns }}$ & 0.5706 \\
Cultivar $\times$ Pollination $\times$ Time & 20 & $1,738.26$ & 86.91 & $1.19^{\text {ns } 1}$ & 0.2752 \\
Error & 120 & $8,769.45$ & 73.07 & & \\
\hline$\%$ Coefficient of variation & $31.48 \%$ & & & &
\end{tabular}

${ }^{1}$ n.s., * and ** non-significant and significant respectively at the $5 \%$ and $1 \%$ level by Duncan's test. 


\subsection{Fruit set and fruit characteristics}

The analysis of variance for fruit set at initial fruit set (17 days after pollination), after June drop (46 days after pollination) and final fruit set (103 days after pollination) is shown in table III. As expected, significant differences were observed among genotypes and cultivars in final fruit setting. All used pollinizers were found compatible to 'Supernova' (table III and figure 1). Significant differences among pollinizers were observed for fruit setting in stages 2 and 3 but there was no significant difference in stage 1 and between the two types of emasculated and non emasculated pollinated flowers ( $t a-$ ble III). The highest fruit set was achieved by using 'Shahrood 21 ' (31.99\%), while the lowest setting recorded when 'Supernova' was forced to self-pollinate (13.10\%) compared to other treatments in this experiment (table III). Results of some agronomical important traits of Supernova and pollinizer cultivars are mentioned in table IV.

Abscising flowers in early stages are due to sterility, imperfect pistils or pollen transfers to the stigma of flowers [29]. Although several pollinizers were used in this experiment, no difference was noticed between the fruit set percentage of the various combinations of pollination (table III). Accordingly, it can be argued that both pistils and pollens used in this study were viable and suitable for pollination. Moreover, the pollen of cv. Supernova had a similar percentage of fruit set compared with those of other pollinizers, even when self-pollinated (table III and figure 1).

Between 17 and 30 days after flowering and pollination, some small fruits dropped due to unsuitable fertilization and lack of embryo. Wind, rain and low temperatures can cause slow growth of pollen tubes in the style making prolonged or even impossible for the pollen tubes to reach the ovary [22]. At this stage, self- and cross-incompatibility are important reasons of small fruit dropping [23,30]. Results obtained from second count of fruit set percentage, confirmed this subject (table III). In the later stages, embryo development and environmental stresses can cause fruit drop in almonds. Although in this study no stress happened on the trees, the fruit drop in third stage can be associated with undeveloped embryo or competition of immature fruits for uptake of nutrients. In the third stage, a lowest fruit set was recorded when 'Supernova' was forced to self-pollinate, what can be related to the type of pollen.

'Supernova' with more than $13 \%$ final fruit set after hand pollination behaved as a self-compatible cultivar. This cultivar showed a lower fruit setting when self-pollinated compared with cross-pollinated by other compatible pollinizers, which is in agreement with the findings of several researchers $[4,24,26$, 30]. However, Torre Grossa et al. [25] observed a higher fruit set after cross-pollination than after self-pollination in the cv. Lauranne, what was not observed by Legave et al. [15] and Dicenta et al. [2] for the same cultivar.

\subsection{Fatty acid composition and oil content}

There were no significant differences among fruits for total oil and major fatty acids (table $V$ ). Nevertheless, the fatty acids 

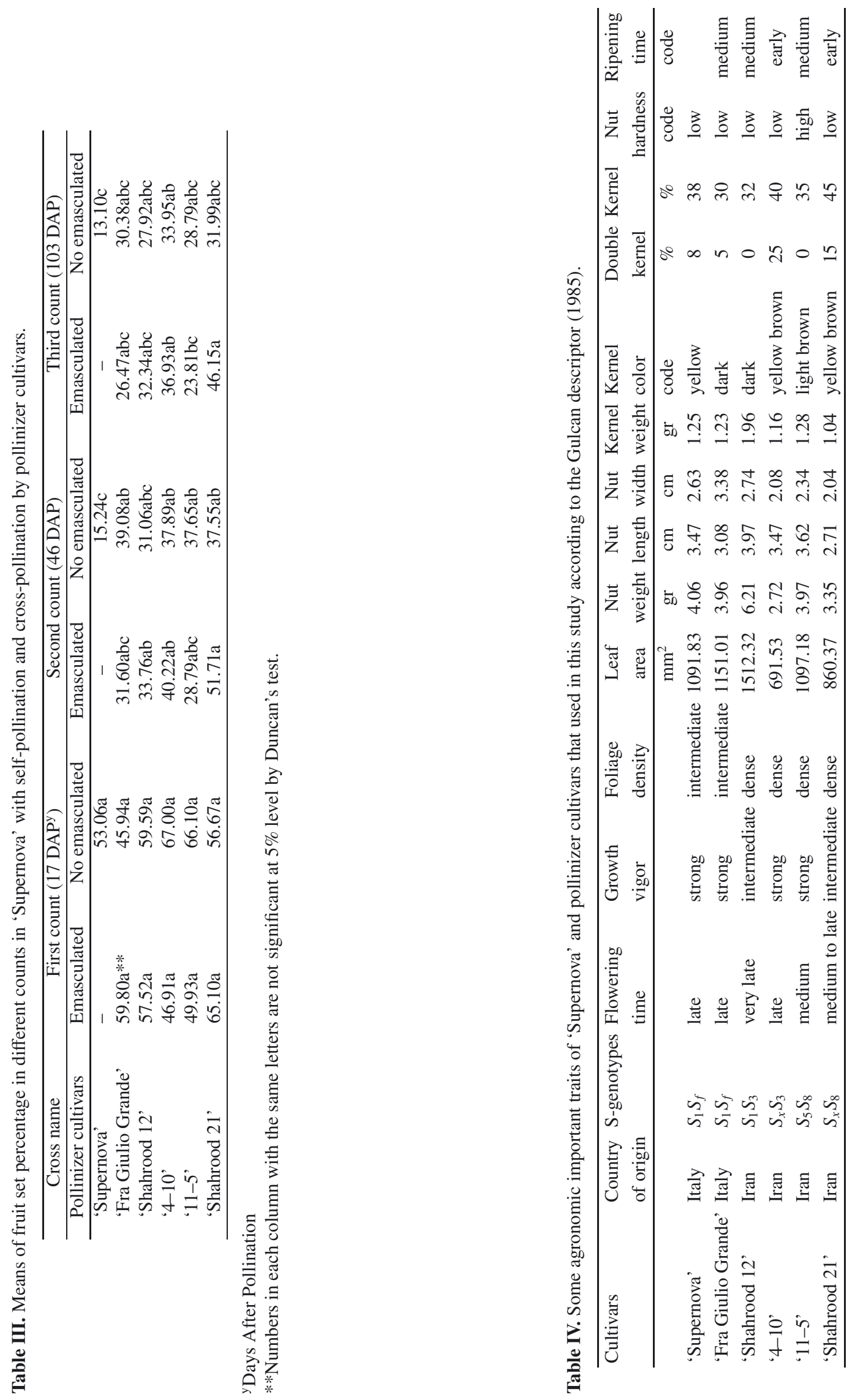


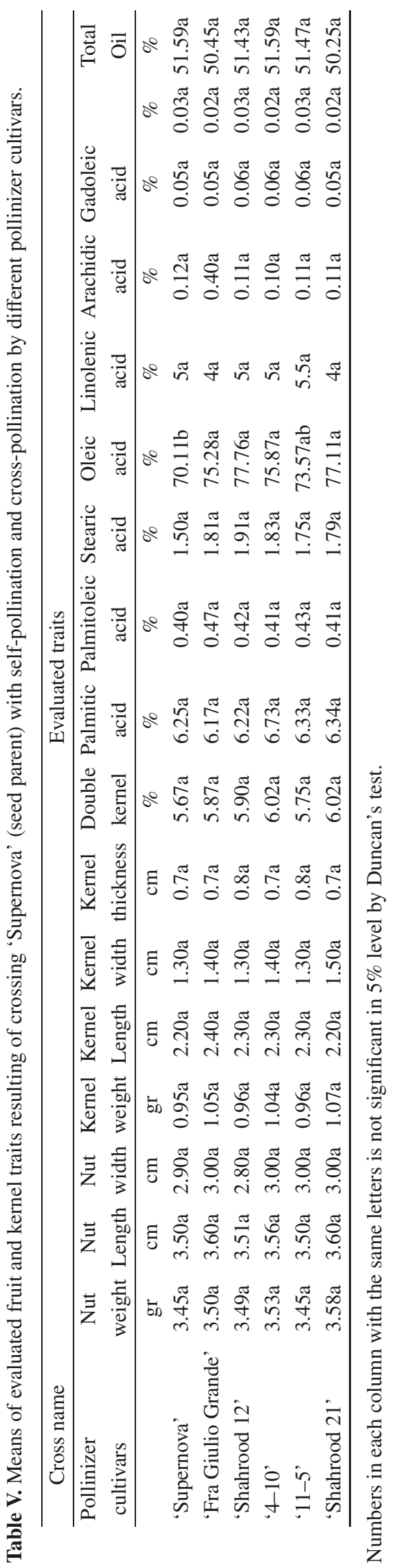

and total oil level in some progenies were somewhat higher than those in the others. Total oil content varied from $50.25 \%$ in $[\mathrm{Sh} 21 \times \mathrm{S}]$ to $51.59 \%$ in $[\mathrm{S} \times \mathrm{S}]$ progenies. Also results indicated that amount of other fatty acids in all treatments were 0.02 to $0.03 \%$ and there were no significant differences between all samples (table $V$ ).

Although, in this experiment pollen type had no effect on fruit oils and fatty acids, but in general, the values obtained represent the proper ratio of fatty acids in the studied fruit (table $V$ ). In this study the amounts obtained were as: oleic acid from 70.11 to $77.76 \%$, linoleic acid from $4 \%$ to $5.5 \%$, palmitic acid from 6.17 to $6.73 \%$, stearic acid from 1.50 to $1.91 \%$, palmitoleic acid from $0.40 \%$ to $0.47 \%$ and 50.25 to $51.59 \%$ oil in assayed fruits (table V). Observations in previous reports $[14,32]$ were discussed according to the present results. This experiment generated for the first time the recorded contents of arachidic acid from 0.10 to $0.40 \%$ and gadoleic acid from 0.05 to $0.06 \%$ in a self-compatible cultivar progeny (table $V$ ). Also, in this assay some progenies had higher contents of oil and major fatty acids than the wild and commercial varieties reported in other studies [10-12,31,33]. Finally, almond progenies resulting from crossing that contains higher oil and major fatty acids than those of commercial varieties could contribute to future nutritionally improved foods.

\section{Conclusion}

Based on all the above points, all used pollinizers were compatible with 'Supernova'. Significant differences among pollinizers were observed on fruit setting at different stages but there was not any significant difference observed between the two types of pollinated flowers. By comparing all treatments used in this study the highest fruit set was achieved by using 'Shahrood 21', while the lowest setting recorded when 'Supernova' was forced to self-pollinate. Also, microscopic observations were consistent with the field results. Cross-pollination had little effect on physico-chemical fruit characteristics of almond such as the amount of some fatty acids in the oil composition. In order to establish almond orchards by 'Supernova' with high yield, 'Shahrood 21', '4-10' and 'Shahrood 12' are recommended. Finally, this study revealed that growing self-compatible almond cultivars in a single-cultivar orchard produces low yield and low productivity. For higher production and economic return it is recommended to plant crosscompatible pollinizers with self-compatible almond cultivars in order to ensure successful pollination and high fruit set.

\section{References}

[1] Kester D.E., Gradzieel T.M., Micke W.C., Identifying pollen incompatibility groups in California almond cultivars, J. Am. Soc. Hortic. Sci. 119 (1994) 106-109.

[2] Dicenta F., Ortega E., Canovas J.A., Egea J., Self-pollination vs. cross-pollination in almond: pollen tube growth, fruit set and fruit characteristics, Plant Breed. 121 (2002) 163-167.

[3] Socias i Company, R., Breeding self-incompatibility almond, Plant Breed Rev. 8 (1990) 313-338. 
[4] Socias i Company R., Felipe A.J., Self-compatibility and autogamy in Guara almond, J. Hort. Sci. Biotech. 67 (1992) 313317.

[5] Duval H., Grasselly C., Behaviour of some self-fertile almond selection in the South-east of France, Acta Hortic. 373 (1994) 69-74.

[6] Godini A., Palasciano M., Growth and yield of four selfunfruitful and four self-fruitful almonds onto three rootstock: A thirteen year study, Acta Hortic. 470 (1997) 200-207.

[7] Vargas F.J., Clave J., Romero M.A., Batlle I., Rovira M., Autogamy studies on almond progenies, Acta Hortic. 470 (1997) 74-81.

[8] Dicenta F., Ortega E., Martinez-Gomez P., Boskovic R., Tobutt K.R., Comparison of homozygous and heterozygous self-compatible seedlings in an almond breeding program, Euphytica 124 (2002) 23-27.

[9] Gratziel T.M., Kester D.E., Breeding for self-fertility in California almond cultivars, Acta Hortic. 470 (1998) 109-117.

[10] Kodad O., Socias i Compan R., Influence of genotype, year and type of fruiting branches on the productive behavior of almond, Sci. Hortic. 109 (2006) 297-302.

[11] Dicenta F., Ortega E., Martinez Gomez P., Sanchez Perez R., Martinez Garcia P.J., Cremates T., Egea J., Breeding lateflowering almonds in the CebasCsic, Murcia, Spain, in: 5th International Symposium on pistachios and almonds, October, 06-10, 2009 Sanliurfa, Turkey.

[12] Kodad O., Socias i Company R., Fruit quality in almond as related to the type of pollination in self-compatible genotypes, J. Amer. Soc. Hortic. Sci. 133 (2008) 320-326.

[13] Marchese A., Boškovic R., Martinez-Gomez P., The origin of the self-compatible almond 'Supernovae', Plant Breed. 127 (2008) 105-107.

[14] Kodad O., Socias i Company R., Variability of oil content and of major fatty acid composition in almond (Prunus amygdalus Batsch) and its relationship with kernel quality composition, Sci. Hortic. 90 (2008) 249-256.

[15] Legave J.M., Richard J.C., Thermoz J.P., Duval H., 'Lauranne', 'Avijor' dans la course, Fruits et Légumes 155 (1997) 36-38.

[16] Grasselly C., Olivier G., Mise en évidence de quelques types autocompatibles parmi les cultivars d'amandier $(P$. amygdalus Batsch) de la population des Pouilles. Annal. Amélior. Plantes 26 (1976) 107-113.

[17] Grasselly C., Olivier G., Difficulté de survie de jeunes semis d'amandiers dans certaines descendances, Options Méditerranéennes 81 (1981) 65-67.

[18] Ortega E., Egea J., Dicenta F., Self-fertilization in homozygous and heterozygous self-compatible almonds, Sci. Hortic. 109 (2006) 288-292.

[19] Salvo F., Dugo G., Cotroneo A., Composition of almond oil. II. Distinction of sweet almond oil from blends with peach and apricot seed oil, Rivista Italiana delle Sostanze, Grasse 57 (1997) 24-26.
[20] Foma M., Abdola T., Kernel oils of seven plant species of Zaire, J. Am. Oil. Chem. Soc. 62( (1985) 910-911.

[21] Gulcan R., Descriptor list for almond (Prunus amygdalus), International Board for Plant Genetic Resources, Rome, 1985.

[22] Ortega E., Dicenta F., Suitability of four different methods to identify self-compatible seedling in an almond breeding program, J. Hortic. Sci. Biotech. 79 (2004) 747-753.

[23] Socias i Company R., Kester D.E., Bradley M.V., Effects of temperature and genotype on pollen tube growth of some selfincompatible and self-compatible almond cultivars, J. Am. Soc. Hortic. Sci. 101 (1976) 490-493.

[24] Oukabli A., Lansari A., Wallali D.L., Abousalim A., Egea J., Michaux-Ferriere, N., Self- and cross-pollination effects on pollen tube growth and fertilization in self-compatible almond Prunus dulcis ‘Tuono', J. Hortic. Sci. Biotech. 75 (2000) 739 744.

[25] Torre Grossa J.P., Vaissiere B.E., Rodet G., Botella L., Cousin M., Besoins on pollination de la variete deamandier autocompatible 'Lauranne', Acta Hortic. 373 (1994) 145-152.

[26] Rasouli M., Fatahi R., Zamani Z., Imani A., Ebadi A., Evaluation of heritability of some traits, genetic control of blooming time and supplementary pollination in almond, Ph.D. Thesis, Factually of Agriculture, University of Tehran, Tehran, Iran (In Persian) (2011).

[27] Ben-Nijama N., Socias i Company R., Characterization of some self-compatible almonds. I. Pollen tube growth, Hort Science 30 (1995) 318-320.

[28] De Graaf B.H.J., Deksen J.W.M., Mariani C., Pollen and pistil in the orgasmic phase, Sex. Plant Reprod. 14 (2001) 41-55.

[29] Martinez-Garcia P.J., Ortega E., Dicenta F., Self-pollination does not affect fruit set or fruit characteristics in almond (Prunus dulcis), Plant Breed. 130 (2011) 367-371.

[30] Martinez-Garcia P.J., Ortega E., Dicenta F., Analysis of the expression of partial self-incompatibility in almond (Prunus dulcis), J. Hortic. Sci. Biotech. 86 (2011) 284-290.

[31] Abbey M., Noake M., Belling G.B., Netsel P.J., Partial replacement of saturated fatty acids with almonds or walnuts lowers total plasma cholesterol and low-density-lipoprotein cholesterol, Am. J. Clin. Nutr. 59 (1994) 995-999.

[32] Çelik F., Fikret Balta M., Kernel fatty acid composition of Turkish almond (Prunus dulcis) genotypes: A regional comparison. J. Food, Agric. Environ. 9 (2011) 171-174.

[33] Moayedi A., Rezaei K., Moini S., Keshavarz B., Chemical compositions of oils from several wild almond species, J. Am. Oil Chem. Soc. 88 (2011) 503-508.

Cite this article as: Mousa Rasouli, Ali Imani. Effect of supplementary pollination by different pollinizers on fruit set and nut physicochemical traits of 'Supernova', a self-compatible almond. Fruits 71 (2016) 299-306. 